\title{
Courts as Participants in "Dialogue": A View from American States
}

\author{
Sanford Levinson*
}

\section{INTRODUCTION: THE DisCOVERY OF “DiALOGUE”}

A perennial topic of interest and debate is the role that courts play, as a descriptive matter, and ought to play, normatively, within any given polity, particularly with regard to enforcement of bills of rights. At least since Alexander Bickel's influential 1962 book The Least Dangerous Branch, ${ }^{1}$ the legal academy has been "obsessed" with the "countermajoritarian difficulty" that Bickel posited. ${ }^{2}$ Like most political scientists, I believe the description of courts as countermajoritarian is considerably overstated, ${ }^{3}$ not least because of the impossibility of explaining precisely why the dominant political leaders of any polity would in fact tolerate genuine countermajoritarian "judicial supremacy" over matters deeply important to them. ${ }^{4}$ It is not surprising, then, that

* W. St. John Garwood and W. St. John Garwood, Jr. Centennial Chair in Law, University of Texas Law School; Professor, Department of Government, University of Texas at Austin. This essay was originally prepared for discussion at a conference on "Judicial Supremacy of InterInstitutional Dialogue: Political Responses to Judicial Review,” in Sydney, Australia, May 18, 2010, and then a workshop on judicial enforcement of bills of rights at the University of Melbourne on May 20. I am grateful to Jack Balkin, Robert Kagan, Michael Paris, and Dan Rodriguez for several very helpful suggestions. I have also benefitted greatly from the opportunity to present earlier drafts to the Boston Area Public Law Study Group and to a faculty colloquium at the Harvard Law School. And, of course, I am delighted by the opportunity given me by the editors of the Kansas Law Review to come to Lawrence and to participate in this important symposium.

1. Alexander M. Bickel, The Least Dangerous Branch (1962).

2. See, e.g., Barry Friedman, The Birth of an Academic Obsession: The History of the Countermajoritarian Difficulty, Part Five, 112 YALE L.J. 153, 155 (2002); see also Barry Friedman, The Counter-Majoritarian Problem and the Pathology of Constitutional Scholarship, 95 Nw. U. L. REV. 933, 933 (2001) (further explaining Friedman's view that constitutional scholars are obsessed with the countermajoritarian problem).

3. See, e.g., Mark A. Graber, The Countermajoritarian Difficulty: From Courts to Congress to Constitutional Order, 4 ANN. Rev. L. \& Soc. SCI. 361, 380 (2008); Mark A. Graber, The Nonmajoritarian Difficulty: Legislative Deference to the Judiciary, 7 STUD. IN AM. PoL. DEv. 35, 37 (1993) [hereinafter Graber, The Nonmajoritarian Difficulty].

4. See, e.g., TOM Ginsburg, Judicial ReVIEW In NeW Democracies: Constitutional COURTS IN ASIAN CASES 22 (2003). This book's importance extends considerably beyond the particular East Asian countries on which Ginsburg focuses. 
much recent writing on the Supreme Court of the United States attacks the "countermajoritarian premise" in favor of an analysis that integrates the Court (and courts more generally) into the dominant political coalitions of an age. ${ }^{5}$

As the debate about countermajoritarianism has somewhat waned, scholars of the judiciary have focused on the notion of dialogue between the judiciary and other institutions that constitute the overall political system. ${ }^{6}$ Of course, the discussion group can be expanded to include the citizenry at large. Second Circuit Court of Appeals Judge Robert Katzmann, the only member of the federal judiciary to have a Ph.D. in political science, has written that "[g]overnance ... is premised on each institution's respect for and knowledge of the others and on a continuing dialogue that produces shared understanding and comity."7 While Professor Barry Friedman has emphasized the notion of dialogue throughout his career, ${ }^{8}$ perhaps the most influential article worldwide has been a 1998 essay by Canadian scholars Peter Hogg and Allison Bushell about the Canadian Charter of Rights and Freedoms. ${ }^{9}$

In any event, it is important to specify the extent to which the notion of inter-institutional dialogue-or, more broadly, dialogue between the judiciary and the general public - is truly helpful, either descriptively in capturing the actual behavior of relevant institutions, or normatively by way of justifying actions of courts that, at least on first appearance, may appear to run counter to contemporary majority opinion, whether as measured by general public opinion polls or by the views of the

5. See, e.g., Lucas A. Powe, JR., The Supreme Court And the American Elite, 17892008, at ix (2009); Keith E. WhitTington, Political Foundations of Judicial Supremacy: THE Presidency, The Supreme COURT, AND CONSTITUTIONAL LEADERSHIP IN U.S. History 4049 (2007). It is always possible, of course, that the integration will be imperfect because of lags that occur when a new political consciousness triumphs at the polls while members of the judiciary, especially those who enjoy life tenure, like U.S. Supreme Court justices, stay on and enforce what many believe to be an outmoded constitutional sensibility. The most famous such occurrence is the "Old Court" that systematically tried to eviscerate the New Deal of Franklin D. Roosevelt before capitulating to the new understanding. Id. at 42.

6. Justice Kennedy, in his opinion in Boumediene v. Bush, referred to "this ongoing dialogue between and among the branches of Government,” 128 S. Ct. 2229, 2243 (2008), quoted in MARK C. MiLler, THE VIEW OF THE COURTS FROM THE HILl: INTERACTIONS BETWEEN CONGRESS AND THE FEDERAL JUDICIARY 6 (2009).

7. ROBERT KATZMAnN, COURTS AND CONGREss 1 (1997), quoted in Miller, supra note 6, at $7-8$.

8. See Barry Friedman, Dialogue and Judicial Review, 91 Mich. L. Rev. 577, 580-81 (1993).

9. Peter W. Hogg \& Allison A. Bushell, The Charter Dialogue Between Courts and Legislatures, 35 OsGOODE HALL L.J. 75 (1997). See also generally Luc B. Tremblay, The Legitimacy of Judicial Review: The Limits of Dialogue Between Courts and Legislatures, 3 INT'L J. CON. L. 617 (2005) (also discussing the Canadian Charter of Rights and Freedoms). 
ostensible representatives of the public who inhabit elected office. Perhaps a better question, especially relevant to dialogical models, is the degree to which courts and other more obviously political institutions are, in fact, self-conscious partners rather than the adversaries that the notion of the "countermajoritarian difficulty" suggests.

Consider in this context the conclusion of Professor Friedman's own recent book on the American Supreme Court, The Will of the People. ${ }^{10}$ What "history teaches," he writes, is that "[a]lmost everything consequential about judicial review occurs after the judges rule, not when they do. Judges do not decide finally on the meaning of the Constitution. Rather, it is through the dialogic process of 'judicial decision-popular response-judicial re-decision' that the Constitution takes on the meaning it has."11 Friedman writes of the "making and enforcing of constitutional meaning" through "an extended dialogue between and among the courts and the American people."12 The dialogue that most interests Friedman is not really among institutions, but rather between the Court and an almost mythic "We the People." ${ }^{13}$ It is, we might say, the "extreme case" of the turn toward "dialogical models" of judicial decisionmaking, though, obviously, no less instructive, because of both its strengths and weaknesses, than more modest models that focus more narrowly, say, on interactions among necessarily elite decisionmakers ensconced in, say, the Supreme Court, the White House, or the Congress. ${ }^{14}$ It is worth noting that Friedman scarcely offers a very precise notion of what he means by "dialogue."

There is at least a rhetorical connection between the emphasis on dialogue and the embrace by some contemporary political theorists of

10. BARRY Friedman, THE WiLl OF THE PEOPLE (2009).

11. Id. at 381-82 (emphasis added).

12. Id. at 384 .

13. In this Friedman may remind some readers of Yale law professor Bruce Ackerman, save that Ackerman is extraordinarily insistent on demonstrating how public opinion in fact operates through the particular institutional structures established by the United States Constitution, including, obviously, the presidency and Congress.

14. See Miller, supra note 6, at 7; J. MitChell PiCKerill, Constitutional Deliberation IN CONGRESS: THE IMPACT OF JUdicial REVIEW IN A SEPARATED SySTEM (2003); see also POWE, supra note 5, at ix (describing the Court as less in dialogue with, than the agent of, those elites in control of the political system). See generally William N. Eskridge, Jr. \& Philip P. Frickey, The Supreme Court, 1993 Term-Foreword: Law as Equilibrium, 108 HARV. L. REV. 26 (1994) (a classic article discussing the dialogue between Court and Congress). Although this article focuses on American courts, it is obvious that similar issues are presented in many other legal systems, whether presidential or parliamentary. Indeed, Hogg and Bushell's seminal article focused on the role of Canadian courts in a decidedly parliamentary system. See generally Hogg \& Bushell, supra note 9 . 
"deliberative democracy."15 A recurrent issue, for example, is what we define as a genuinely "deliberative" process. If one is a Habermasianor, for that matter, a devotee of Bruce Ackerman-there will be a great emphasis placed on the "undominated" nature of the conversation, so that whatever closure is reached is not the product of the greater power of one of the ostensible conversant, but rather an agreement produced by the power of true reason, as it were. ${ }^{16}$ One might recall a reference many decades ago by another Yale professor, Eugene V. Rostow, to "[t]he Supreme Court [as], among other things, an educational body, and the Justices are inevitably teachers in a vital national seminar." ${ }^{17}$ A first-rate seminar may indeed feature a great deal of dialogue and changes of mind based on the evidence and force of argument, but, with few exceptions, there is also no doubt as to who is supreme as between the "teachers" and the "students." Presumably devotees of dialogical models wish to flatten that distinction and to diminish the judiciary's role as teacher, at least if by that metaphor we mean the power to give binding grades. Moreover, one might well wish to distinguish between some kind of genuinely public-spirited dialogue, in which all participants are motivated by a desire to achieve something that might be captured by the term "general welfare," as against their being motivated by more private interests that transform the dialogue into what can more accurately be called a "bargaining process." To the extent that one speaks, for example, of a dialogue between courts and legislatures - or any other bodies, including the general public-is one thinking more of an idealized Platonic symposium or of an encounter that one might have, say, with a car salesman when searching for a new car? There are, no doubt, significant exchanges of information between the buyer and the seller in the latter instance, but would we really describe it as a "dialogical encounter" that should model our politics?

Consider in this context Walter F. Murphy's classic book Elements of Judicial Strategy, perhaps the earliest book to elaborate the extent to which any savvy judge is intimately aware of the potential responses from other actors in the political system, whether colleagues on the bench or members of other institutions that are being asked-or, in theory, "ordered"-to implement a judicial decision or who might

15. The literature on deliberative democracy has itself become enormous. See, e.g., AMY

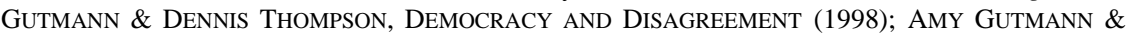
DENNIS THOMPSON, WHY DELIBERATIVE DEMOCRACY? (2004).

16. See Bruce A. Ackerman, Social Justice in the Liberal State 8-10 (1980).

17. Eugene V. Rostow, The Democratic Character of Judicial Review, 66 HARV. L. REV. 193, 208 (1952). 
nonetheless possess certain powers over the court, such as control of jurisdiction or salary, that might need to be taken into account when deciding how truly "innovative" to be. ${ }^{18}$ Indeed, graduate students can undoubtedly recall seminars in which a great deal of such "strategic" encounters took place in an effort to ingratiate oneself with a powerful professor. One presumes that such strategic thinking is not exemplary of the kinds of dialogue that proponents of dialogical models have in mind. It is not clear to me that legislative responses to judicial review necessarily count as dialogue rather than, say, a play in a bargaining game by which the respondent legislature makes a counteroffer to the court in the hope that the court, recognizing the exigencies of the political situation, will accept it and shut down further inquiry.

The prior paragraph has touched, much too briefly, on some conceptual difficulties surrounding the term "dialogue." But, of course, there are also significant empirical issues involved as well, even if we agree on the underlying concept. Friedman has been rightly criticized for his failure to present a robust empirical argument on how exactly this "dialogue" takes place between Court and public. ${ }^{19}$ After all, as Nathan Persily writes in his introduction to a recent book, Public Opinion and Constitutional Controversy, "[f]or the most part, the decisions of the Supreme Court and other courts go unnoticed by the American public."20 "For the most part," obviously, does not mean "never," and one can easily cite examples of those relatively few cases that in fact do draw public notice. Even there, however, one can be absolutely confident that extremely few members of the public-or, perhaps, anyone elseactually read the judicial opinions themselves. ${ }^{21}$ Almost all information about the opinions comes to the public as filtered through various media, which, in today's world, can mean practically anything. As anyone who has ever played the telephone game knows, messages can become quite transformed from the initial speaker to even the third or fourth one down the line, and it may be quite foolhardy to believe that any given speaker represents the public. Friedman often relies, for example, on reporters

18. See generally Walter F. Murphy, Elements of Judicial Strategy (1964).

19. See, e.g., Justin Driver, Why Law Should Lead, THE NEW RePUBLIC, Apr. 2, 2010, at 28-32, available at http://www.tnr.com/article/books-and-arts/why-law-should-lead (book review criticizing "analytical trouble" in Friedman's The Will of the People).

20. Nathaniel Persily, Introduction to PUBLIC OPINION AND CONSTITUTIONAL CONTROversy 3 , 9 (Nathaniel Persily et al. eds., 2008).

21. One might well wonder how many Americans have actually slogged through the more than 200 pages of combined opinions in the recent McDonald case that "incorporated" the Second Amendment against the states (and city of Chicago). McDonald v. City of Chicago, 130 S. Ct. 3020 (2010). 
and pundits from the New York Times for his views on what "the public" believes; one need not be a raving populist to doubt that Times columnists are mimetic of the general American public. But even more constrained dialogical models, which focus, for example, only on a call by the judiciary and a subsequent response by a legislature, may run into similar empirical difficulties. Does anyone believe, for example, that members of Congress actually read judicial opinions instead of relying on one- or two-page memos from staff (who may, of course, be legally trained) that ostensibly capture the gist of far longer opinions (including concurrences and dissents)?

\section{Why STATE Constitutionalism PROVIDES A MODEL FOR DiAlogue ABOUT “Dialogue”}

My own contribution to this examination of intra-institutional and wider public dialogues involves a somewhat unlikely perspective: American state constitutions and their interpretation by state supreme courts. Like many students of constitutionalism, I am increasingly insistent on a comparative turn and therefore critical of the almost exclusive emphasis placed by American "constitutional lawyers" and theorists on the United States Constitution. Much very fine work, of course, involves cross-national comparisons. Although I have indeed become more interested in cross-national comparison, I find myself increasingly focusing on a rich source of comparative material within the United States-state constitutions. One reason is simply the reality, as Robert Williams has written, that "[i]n the last quarter of the twentieth century, American state courts emerged as major policy makers, taking their place alongside federal courts as important judicial actors in governmental lawmaking., ${ }^{22}$ That would be enough to justify the turn to American state courts and the constitutions they often interpret. ${ }^{23}$

But I should confess that one of the agendas of this paper is to attack the premise, basically as prevalent in the United States as in the rest of the world, that there is a distinctly "American form" of constitutionalism that can be found either by close conceptual analysis of the United States

22. Robert F. Williams, The Law of American State Constitutions 283 (2009). See also generally Sanford Levinson, America's "Other Constitutions": The Importance of State Constitutions for Our Law and Politics, 45 TULSA L. REV. 813 (2011) (reviewing Williams).

23. And, incidentally, American state constitutions should also be of great interest to anyone concerned with the empirical consequences of different institutional structures, for there are often surprising differences in basic political organization between any given state and the United States and among states themselves. 
Constitution-including its historical development over the past 220 years - or by an exclusive focus on the handiwork of the United States Supreme Court. Friedman's book is an example of the latter, as is, I must admit, Robert McCloskey's The American Supreme Court, originally published in 1960 but published more recently in updated editions that I have written. ${ }^{24}$ One need not renounce such work in order to acknowledge, for example, that almost all of the 300+ million residents of the United States-save those who reside in the District of Columbia-live under two constitutions, one the United States Constitution, the other the constitution of the state in which that person happens to live. Indeed, things can become even more complex for certain enrolled members of American Indian tribes who may also be subject to tribal constitutions. ${ }^{25}$

Or consider "cosmopolitans," rootless or otherwise, who might live, in any given year, in more than one state, similar to international cosmopolitans with homes or businesses in different countries who may be subject to more than one national constitution. And a full accounting, in many parts of the world, might include "transnational" quasiconstitutions like the European Convention of Human Rights or the complex treaty systems enforced by the European Court of Justice, even before turning to the ever-uncertain status of "international law." Even if one believes that there is a strong "hierarchy" among these various legal systems so that in case of conflict, one can always predict the winner, there is, very often, no such conflict, particularly if the criterion of conflict is contradiction. Often the various constitutions are significantly complementary, in which an issue on which the ostensibly superior constitution is silent may well be resolved by what, from a conceptual standpoint, is a "subordinate" law. Ranking superior and subordinate legal systems raises interesting theoretical problems and is, of course, often important to actual litigants. But we should also recognize the frequency with which the issues raised by rank ordering are only theoretical—or, one might even say, "academic" in the pejorative sense. Most litigants — and many other persons as well—are primarily interested in which institution or institutions can act, as a practical matter, with final authority, and often these are states or, in those states that grant

24. See generally Robert MCCloskey, The AmERICAN Supreme Court (5th ed. 2010).

25. See, e.g., Native American Constitution and Law Digitization Project, UNIV. OF OKLA. L. LIBRARY, http://thorpe.ou.edu/const.html (last visited Apr. 1, 2011) (a compendium of tribal constitutions within the United States). 
"home rule" to municipalities as a matter of state constitutional right, even cities. $^{26}$

"When Americans speak of 'constitutional law,"” James Gardner has written, "they invariably mean the U.S. Constitution and the substantial body of federal judicial decisions construing it." 27 Another notable scholar of American state constitutions has described them as "lowvisibility constitutions in the United States, ${ }^{, 28}$ not least because those who teach constitutional law in American law schools have a decidedly reductive view of their subject. As former Oregon state justice Hans Linde-who is also a distinguished legal academic - wrote, "[g]eneral constitutional law courses, which everyone takes, create the impression that contemporary majority opinions and dissents in the United States Supreme Court exhaust the terms as well as the agenda of constitutional litigation." ${ }^{29}$ In a recent lecture tellingly titled Why Teach-and Why Study-State Constitutional Law, Jeffrey S. Sutton, a member of the United States Court of Appeals for the Sixth Circuit who is also an adjunct professor at the Ohio State University, describes state constitutional law as "an underdeveloped area of the law," and he notes that of the twenty-four law schools that offered a course in 2007-08 on "State Constitutional Law"-as distinguished from state-specific state constitutional law courses-not one was rated by U.S. News and World Report within the top fifteen law schools in the United States. ${ }^{30}$

One might easily explain and perhaps justify this disregard of state constitutions if it were the case that the state governments established by these constitutions dealt with mere trivialities of no interest to ordinary people-or even if they raised no interesting interpretive issues of the kind that obsess legal academics. But neither is remotely true; indeed, the premise is laughably_and sometimes tragically_false. As to the first, consider only such obvious issues as land use and taxation, among the most predictably volatile of all political issues, and which are present,

26. See, e.g., Lynn Baker \& Daniel B. Rodriguez, Constitutional Home Rule and Judicial Scrutiny, 86 DENV. U. L. REV. 1337, 1340-41 (2009). See also generally Jessica Bulman-Pozen \& Heather K. Gerken, Uncooperative Federalism, 118 YALE L.J. 1256 (2009) (noting the circumstances under which ostensibly subordinate states can affect, and in some circumstances even subvert, federal programs that are purportedly binding).

27. JAMES A. GARDNER, INTERPRETING STATE CONSTITUTIONS 23 (2005).

28. WiLliams, supra note 22, at 1.

29. Hans A. Linde, State Constitutions Are Not Common Law: Comments on Gardner's Failed Discourse, 24 RUTGERS L.J. 927, 933 (1993).

30. Jeffrey S. Sutton, Speech, Why Teach-and Why Study-State Constitutional Law, 34 OKLA. City U. L. REV. 165, 166-67 (2009). I am grateful to Justin Driver for drawing this article to my attention. 
directly and indirectly, in the financing of public schools. As Daniel Rodriguez asserts, "the basic range of policies and policy choices made by state and local officials dwarf-indeed always have dwarfednational political activity." ${ }^{31}$ Many of these choices, of course, may be made "in the shadow" of the national Constitution or of potentially preemptive congressional statutes, but some significant number are made basically autonomously and, in cases like those considered in this essay, in light of state constitutional norms. One can debate whether the United States has a robust federalism, especially if we define that term by reference to constitutionally entrenched autonomy of sub-national units with regard to issues of significant public importance. ${ }^{32}$ There can, however, be little doubt that as a matter of fact, many issues of great public importance are decided within the states and that state constitutions are frequently thought to be relevant to such decisions. Even if Congress could displace all such decisions through federal legislation, we know both that Congress has not done so and is quite unlikely to do so in the foreseeable future. And anyone who dips into state constitutional cases quickly finds interpretive dilemmas that are no less interesting than those generated by the denizens of the United States Supreme Court.

Some of the disdain for state level constitutionalism may be explained by a somewhat odd debate in the United States about what might be termed the ontological status of these state constitutions. ${ }^{33}$

31. Daniel B. Rodriguez, State Constitutionalism and the Scope of Judicial Review, in NEW Frontiers in STATE CONSTITUTIONAL LAW: DUAL ENFORCEMENT OF NoRMS 61, 65 (James A. Gardner \& Jim Rossi eds., 2010). Similarly, a recent editorial in the New York Times by former Justice Sandra Day O’Connor, who had been both an elected official and a state judge in Arizona, states that "[s]tate courts resolve the most important legal matters in our lives, including child custody cases, settlement of estates, business-contract disputes, traffic offenses, drunken-driving charges, most criminal offenses and most foreclosures." Sandra Day O’Connor, Take Justice Off the Ballot, N.Y. TIMES, May 23, 2010, at WK9. She presents this in the context of a column condemning the way that most states currently elect their judges. Id. Obviously, most of the examples chosen by former Justice O'Connor rarely involve constitutional issues as such, although states often have state-constitutionally-mandated norms of criminal procedure that differ in important ways from national norms as interpreted by the Supreme Court. For example, eleven states extend "constitutional protection to privacy, which has been interpreted as affording a broader substantive right than the Fourth Amendment's search-and-seizure clause.” Helen Herschkoff, State Common Law and the Dual Enforcement of Constitutional Norms, in NEW FRONTIERS IN STATE CONSTITUTIONAL LAW, supra, at 151, 158.

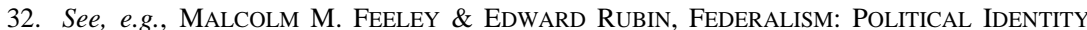
AND TRAGIC COMPROMISE 124-49 (2008) (arguing that American federalism is both very weak and, to the extent it exists at all, basically unfortunate_-as distinguished from "decentralization," which is a non-constitutionally-demanded political choice with regard to the creation or implementation of given public policies).

33. Thus, James A. Gardner, one of the leading writers on state constitutions, declared that 
Some scholars suggest they are not "genuine" constitutions precisely because they are all subordinate to the national Constitution and thus do not have a seemingly requisite degree of sovereign capacity. ${ }^{34}$ Others note that it is implausible to view state constitutions as instantiating a particular people and treat this as a predicate condition for something to count as a "real constitution." 35 To be sure, whatever might once have been the case, it is difficult to view most, if any-perhaps Texas is the exception - of the American states as being a truly distinct community from its neighbors. ${ }^{36}$ Even if, as Justice Antonin Scalia asserts, a defining characteristic of the United States Constitution is precisely that it speaks in the name of a distinctive "We the American People",37 which means, among other things, that its interpretation should not depend on developments emanating from some other people across the seas-it is difficult to make such an argument with regard to state constitutions. After all, not only were many American state constitutions borrowed from prototypes adopted by earlier states-from which the newcomers might well have left in their treks westward ${ }^{38}$ - but one also regularly finds within state court decisions citations to the decisions of other state courts as persuasive, even if not binding, authority. To be sure, this can be explained on the basis that state courts are all common law courts, as well as interpreters of their state constitutions and statutes in a way that federal courts are not. However, this explanation serves to undercut what might be labeled as an "organic nationalist" view of a given state.

Moreover, as already suggested, it is crystal clear, thanks to Article VI of the United States Constitution, that no state constitution can withstand the force of an otherwise constitutional statute passed by Congress or a clause of the United States Constitution that demands more protection of a given right than might be accorded by the state

"state constitutions, to put it bluntly are not 'constitutions' as we understand the term.” James A. Gardner, What Is a State Constitution?, 24 RUTGERS L.J. 1025, 1026 (1993).

34. James A. Gardner, The Failed Discourse of State Constitutionalism, 90 Mich. L. REV. 761, 774-75 (1992).

35. See id. at 833.

36. See, e.g., Paul W. Kahn, Community in Contemporary Constitutional Theory, 99 YALE L.J. 1, 3 (1989) ("Community functions not as a geographical place, but as a conceptual model of order that combines elements of reason and will.”).

37. See generally Sanford Levinson, Looking Abroad When Interpreting the U.S. Constitution: Some Reflections, 39 TEX. INT'L L.J. 353, 355 (2004) (discussing Justice Scalia's reluctance to use foreign law and custom in interpreting the Constitution).

38. See WiLliams, supra note 22, at 86-87 ("state conventions built on the state constitutional experience of other states"). 
constitution. $^{39}$ There is a rigid hierarchy that clearly places the United States Constitution in a position of superiority. And, at least in theory, an Article $\mathrm{V}$ amendment rejected by one-fourth of the states-but not the vital one-fourth plus one-could radically transform existing state polities. But I'm tempted to ask, so what? After all, an increasing number of national constitutions are part of complex transnational and international legal systems that put national law "in its place," which may be subordinate to the transnational norms. One wonders if these analysts will soon be arguing that the constitutions of France and Germany, among others, can also be dismissed as lacking "essential" attributes of constitutions inasmuch as these countries-like all members of the European Union-are increasingly enmeshed in what almost any American lawyer or political scientist would describe as a European "constitutional order." It is also worth noting that Great Britain scarcely serves any longer as a knock-down example of a country with no written constitution because it has embraced an order that courts enforce with increasing vigor.

Other scholars, in addition to emphasizing the "inferior" place of state constitutions in the American constitutional hierarchy, also note that few, if any, state constitutions have been treated with the veneration that, I believe unjustifiably, ${ }^{40}$ is directed to the United States Constitution, which is treated as the "sacred text" of the American civil religion. ${ }^{41}$ But to demand veneration as a criterion of constitutionalism would call into question the status of many, perhaps the overwhelming majority of, national constitutions, which, like American state constitutions, are treated as objects of instrumental analysis rather than sometimes thoughtless devotion. Even if one can place constitutions along a spectrum of their hold over the popular imagination, one should be willing to concede that constitutions with relatively limited hold remain constitutions until one presents evidence to the contrary, as by demonstrating that no one really cares what the constitution says or that it is never enforced in any meaningful sense by political authorities. This might well have been the case with the vaunted Soviet constitutions. But even the old joke about the person who goes to the library and asks for a copy of the French constitution, only to be told that it is available in the periodicals room, takes on new meaning when one realizes that the most recent French constitution, establishing the Fifth Republic, has provided

39. See U.S. CONST. art. VI, cl. 2.

40. See SANFORD LEVINSON, OUR UndemocratiC CONSTITUTION: Where the Constitution Goes Wrong (and How We the PeOPle CAN CORRECT IT) 16-19 (2006).

41. See SANFORD LEVINSON, CONSTITUTIONAL FAITH 12-13 (1988). 
a relatively stable structure of governance for a full half-century, and one cannot understand the modern French polity without paying at least some attention to its constitution. ${ }^{42}$ It has, after all, lasted almost three times as long as the median survival of all national constitutions since 1789, which is only nineteen years. ${ }^{43}$

There is, therefore, no good reason to ignore the immensely interesting data available to anyone who is willing to take a look at the fifty state constitutions within the United States. ${ }^{44}$ Indeed, it may be scholarly malpractice to do so. Even the most cursory examination reveals the accuracy of John Dinan's argument that there is a-or perhaps are several-distinctive "American state constitutional tradition(s)" 45 that challenge much of what is found in the 1787 Constitution. To be sure, one might readily point to important similarities as well-no American state, for example, has rejected separation of powers and a separately elected governor in favor of a parliamentary system where the governor would be selected by and required to maintain the confidence of a majority of the legislature. ${ }^{46}$ Still, with regard especially to the judiciary, the differences between state and national constitutions and institutions are striking and worth attending to.

What are some of these differences? If we begin by looking at the organization of the judiciaries themselves, we immediately discover that "[a] large majority of state judges face the electorate in either partisan, non-partisan, or merit-retention elections." ${ }^{47}$ Indeed, a recently published article begins by noting that "[a]lmost ninety percent of state judges face some kind of popular election. Thirty-eight states put all of

42. See John Bell, French Constitutional LaW 241 (1992) (noting that a very large amount of legal continuity has been achieved).

43. ZaChary ElKinS ET AL., The Endurance OF NATIONAL Constitutions 129 (2009). And, for what it is worth, it has lasted a full seven times longer than America's "first Constitution," the Articles of Confederation, which were ratified in 1781 and suffered an inglorious demise with the ratification of the supplanting Constitution in 1788.

44. See Neal Devins, How State Supreme Courts Take Consequences into Account: Toward a State-Centered Understanding of State Constitutionalism, 62 STAN. L. REV. 1629, 1691 (2010) (describing how "state constitutional systems borrow from each other"). I am grateful to Professor Devins for giving me the opportunity to read his article before its publication.

45. See generally John J. Dinan, The American State Constitutional Tradition (2006) (discussing this "tradition”).

46. Though, as a matter of fact, Rhode Island adopted a full separation of powers system only in 2004, following decisions of the Rhode Island Supreme Court holding that Rhode Island did not have such a system. See Carl T. Bogus, The Battle for Separation of Powers in Rhode Island, 56 ADMIN. L. REV. 77, 78 (2004).

47. WiLliams, supra note 22, at 285. 
their judges up before the voters." 48 And no American state judge, elected or appointed, save in Rhode Island, is entitled to serve for life. ${ }^{49}$ In each of the other few states that do not have term limits, there is a retirement age of seventy. ${ }^{50}$ Moreover, even in non-election states, few allow their governors to exercise President-like control over the

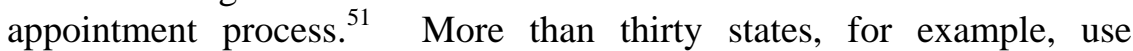
"commissions" to select candidates whose names are then given to governors to choose from. ${ }^{52}$ As already noted, in forty-seven of the fifty states, judges serve restricted "terms" of office-though they are eligible to run for re-election or reappointment. In twelve states, judges are subject to being "recalled" by the voters should they issue presumably outrageous decisions. ${ }^{53}$ Although not technically "recalls," shockwaves were certainly felt throughout state judiciaries by the unprecedented decision of Iowa voters to reject three justices running in so-called "retention elections," in which voters are asked whether they wish to "retain" incumbent judges who appear alone on the ballot-not facing

48. Jed Handelsman Shugerman, Economic Crisis and the Rise of Judicial Elections and Judicial Review, 123 HARV. L. REV. 1061, 1063-64 (2010).

49. See Devins, supra note 44, at 1645-47.

50. A tribute to former New York Chief Judge Judith Kaye by her successor begins, "Judith S. Kaye's constitutionally mandated retirement [as she had turned seventy] from the bench on December 31, 2008, brought to a premature end her magnificent twenty-five-year career on the New York Court of Appeals, including almost sixteen years as Chief Judge of the State of New York." Jonathan Lippmann, Chief Judge Judith S. Kaye: A Visionary Third Branch Leader, 84 N.Y.U. L. REV. 655, 655 (2009). One might contrast this with the insistence of the terminally ill eighty-yearold William Rehnquist on remaining Chief Justice of the United States until his death in July 2005.

51. An interesting exception is New Jersey, the topic of much discussion below. In New Jersey, justices are initially appointed to the New Jersey Supreme Court by the Governor and with the confirmation of the Senate for a seven-year term, at which time they are eligible for, and almost always are given, an appointment until the retirement age of seventy. See Devins, supra note 44, at 1676 n.248. Recently, the newly inaugurated Republican Governor of New Jersey refused to reappoint a member of the court-who happened to be the one African-American member - on the grounds that the justice in question was presumably exemplary of what the new Governor "described [as an] historically liberal court [that went] 'out of control' over the last three decades, usurping the roles of the governor and the Legislature in setting social and tax policies.” Richard Pérez-Peña, Christie, Shunning Precedent, Drops Justice from Court, N.Y. TimES, May 4, 2010, at A22, available at http://www.nytimes.com/2010/05/04/nyregion/04christie.html. The Times story concludes, "Mr. Christie will have a chance to reshape the court. In his four-year term, five of its seven members (including Justice Wallace) will reach either mandatory retirement or the end of their initial seven-year appointments." Id. For what it is worth, I was surprised during a 2009 visit to Australia to discover that the Prime Minister-presumably with the consent of the Cabinetapparently had carte blanche with regard to naming the new Chief Justice of the Australian High Court.

52. Sandra Day O’Connor, The Essentials and Expendables of the Missouri Plan, 74 Mo. L. REV. 479, 486 (2009).

53. DinAN, supra note 45, at 135. 
what might be termed "live opposition."54 All three had recently joined in a unanimous decision of the Iowa Supreme Court that found same-sex marriage to be protected by the Iowa Constitution, altogether independently of the Fourteenth Amendment of the United States Constitution. $^{55}$ No state has abolished judicial review, although Kentucky attempted to do so for a brief time in the $1820 \mathrm{~s} ;{ }^{56}$ two states, however, North Dakota and Nebraska, require supermajority votes in order to invalidate a state law as unconstitutional. ${ }^{57}$

In contrast to the United States Constitution, which has been construed by the Supreme Court to require "cases and controversies" and therefore to prohibit advisory opinions on pending legislation, ${ }^{58}$ the supreme courts of eight states are authorized or even required to render such opinions. ${ }^{59}$ As Robert Williams has written, "when state supreme courts issue advisory opinions, they act more like European constitutional courts than the United States Supreme Court." 60 Moreover-note I don't say "finally"- there is the fact that it is easier to amend the constitution of every state than it is to amend the United States Constitution, which is, indeed, the hardest-to-amend constitution in the entire world. ${ }^{61}$

One example of this was recently seen in California, where Proposition 8 overturned a decision of the California Supreme Court

54. See A. G. Sulzberger, In Iowa, Voters Oust Judges Over Marriage Issue, N.Y. TIMES, Nov. 3, 2010, http://www.nytimes.com/2010/11/03/us/politics/03judges.html (quoting Bob Vander Plaats, who led the campaign against the judges after losing his race for the Republican nomination for governor, speaking to "a crowd of cheering supporters at an election night party peppered with red signs declaring 'No Activist Judges'”: “'I think [the Iowa vote] will send a message across the country that the power resides with the people. It's we the people, not we the courts.'”). The shockwaves could certainly be felt, so to speak, at the Kansas Law Review symposium held just ten days later. See Todd. E. Pettys, Letter from Iowa: Same Sex Marriage and the Ouster of Three Justices, 59 U. KAN. L. REv. 715 (2011); see also Editorial, A Blow to the Courts, N.Y. TIMES, Nov. 9, 2010, at A34, available at http://www.nytimes.com/2010/11/09/opinion/09tue3.html (arguing that "[t]his year's campaign is one more reminder of why the 39 states that hold judicial elections should scrap them in favor of merit screening and appointment of judges for a long fixed term.").

55. Varnum v. Brien, 763 N.W.2d 862, 872 (Iowa 2009).

56. Theodore W. Ruger, "A Question Which Convulses a Nation”: The Early Republic's Greatest Debate About the Judicial Review Power, 117 HARV. L. Rev. 827, 850-55 (2004).

57. The supermajority requires four out of five justices in North Dakota and five out of seven in Nebraska. DinAN, supra note 45, at 134.

58. Buckley v. Valeo, 424 U.S. 1, 11-12 (1976).

59. WILLIAMS, supra note 22, at 296.

60. Id.

61. See Donald Lutz, Toward a Theory of Constitutional Amendment, in ResPonding to IMPERFECTION: THE THEORY AND PRACTICE OF CONSTITUTIONAL AMENDMENT 237, 261 (Sanford Levinson ed., 1995). This title used to be held by the Yugoslav Constitution, which, of course, is no longer operative. $I d$. 
establishing a right, under the California constitution, to same-sex marriage. ${ }^{62}$ It is of telling significance that the Proposition was placed on the ballot by "popular initiative"-without the assent of the California legislature-and then adopted by a majority vote in the ensuing general election. ${ }^{63}$ At the very least, this demonstrates the ability of an aroused majority to overrule what would otherwise be binding constructions of the state constitution by simple majority vote. Thus, one author has written that state judiciaries by and large exemplify "the majoritarian difficulty" rather than the converse that so dominates discussion of the Supreme Court: "The majoritarian difficulty asks not how unelected/unaccountable judges can be justified in a regime committed to democracy, but rather how elected/accountable judges can be justified in a regime committed to constitutionalism." 64 All of this amply supports Professor Hershkoff's comment that "state court decisions are not the last word in a political conversation, but rather the first, opening a dialogue with the legislature and the people and spurring the development of shared solutions to important public problems.”65 One might regard these "uniquely American" ${ }^{\text {"6 }}$ features of state judiciaries - and the wider political structure of which they are a part-with pleasure, horror, or Olympian indifference, but it is hard to believe that they do not generate quite different kinds of dialogue from those generated, say, by the United States Supreme Court.

One might also suspect that state judges, even those serving on their highest courts, are less cosmopolitan or otherwise drawn from national elites than-certainly-United States Supreme Court justices. By the same token, I strongly suspect, although have not done the research to demonstrate, that more state supreme court justices have had some kind of political career prior to their joining the judiciary than, most certainly, is currently the case for the United States Supreme Court, which, since the retirement of Sandra Day O'Connor, lacks for the first time in its history anyone who has ever successfully—or perhaps even

62. See, e.g., Tamera Audi et al., California Votes for Prop 8, WALL St. J., Nov. 5, 2008, http://online.wsj.com/article/SB122586056759900673.html.

63. Id.

64. Steven P. Croley, The Majoritarian Difficulty: Elective Judiciaries and the Rule of Law, 62 U. CHI. L. REV. 689, 694 (1995), quoted in Helen Hershkoff, Positive Rights and State Constitutions: The Limits of Federal Rationality Review, 112 HARV. L. REV. 1131, 1160 n.163 (1999).

65. Hershkoff, supra note 64, at 1169. One notes how closely Friedman tracks this language in his book, but, I must say, I think there is far greater explanation of how and why a "dialogical model" might be present in states than at the level of the Supreme Court.

66. Shugerman, supra note 48 , at 1064. 
unsuccessfully—run for any political office. ${ }^{67}$ This is in vivid contrast to earlier courts, whose ranks have notably included, in the twentieth century alone, a former Governor of New York and candidate for the presidency in Charles Evans Hughes, a former President of the United States in William Howard Taft, and a former Governor of California who was a candidate for the vice presidency in 1948 in Earl Warren, not to mention such distinguished senators as George Sutherland and Hugo Black. President Obama's two selections for the Court did nothing to change this situation, whatever their undoubted strengths might have been. $^{68}$ It is hard to believe that such experience is irrelevant to the perspectives that judges take, especially when faced with cases that obviously implicate important issues of public policy in which designing what are thought to be effective remedies to implement the Constitution present far more of a challenge than churning out an argument about what abstract rights are-or are not-protected by the Constitution itself. $^{69}$

Quite frankly, it is equally hard to believe that the take-charge-anddo-something-about-problems attitude often associated with successful politicians does not transfer over in significant measure to service as a judge, whatever conventional wisdom might suggest about judicial restraint. A recent article by Frank Cross and Stefanie Lindquist has adverted to specific “judicial types," including, in a term initially proffered by Professor J. Woodford Howard, judicial "innovators" who "“felt obliged to make law whenever the opportunity occurs."”70 This may be particularly telling in state courts, which, of course, are charged with continuing common-law decisionmaking and creation, where self-

67. On the backgrounds of state judges, see the report on a sixteen-state study of state supreme courts conducted by Robert Kagan, Lawrence Friedman, and Stanton Wheeler in the 1970s. Robert A. Kagan et al., American State Supreme Court Justices, 1900-1970, 1984 AM. B. FounD. RES. J. 371. Among other things, less than half of state supreme court judges sitting between 1950 and 1970 had as much as five years prior judicial experience before reaching the highest court. Id. at 376.

68. As it happens, the current Supreme Court is also the first one since its creation in 1789 to lack even a single member with experience serving on a state court. Both Justices O'Connor and Souter had served as judges in their home states of Arizona and New Hampshire, respectively. In addition, Justice Brennan, perhaps the most important post-World War II liberal justice, had been a distinguished member of the New Jersey Supreme Court prior to his 1956 selection by President Eisenhower for the United States Supreme Court.

69. See generally RICHARD H. FALLON, JR., IMPLEMENTING THE CONSTITUTION (2001) (discussing the challenge for Supreme Court Justices of "developing a workable doctrinal structure").

70. Frank B. Cross \& Stefanie Lindquist, Judging the Judges, 58 DuKE L.J. 1383, 1415 (2009) (quoting J. WOODFORD HOWARD, JR., COURTS OF APPEALS IN THE FEDERAL JUDICIAL SYSTEM 160 (1981)). 
conscious policy considerations are deemed more appropriate than in the peculiar world of federal courts.

Cross and Lindquist also offer the linked notion of the "judicial entrepreneur," who, like "policy entrepreneurs" more generally, delight “"in identifying problems and finding solutions.,"71 "Like any entrepreneur," Cross and Lindquist write, "to be successful the judge must have a product that appeals to the relevant market and must be able to effectively sell that product."72 Thus, "dialogue" may be just another name for what is in effect an advertising campaign, by which innovative-or, if one wishes, "activist" or "rampaging"-jurists try to sell their ideas to some mixture, depending on the specifics of the political system, of public officials and the public in general as part of an effort to address what the judge believes to be a pressing problem facing the polity. Indeed, not only might one expect former politicos to be more likely to embark on "entrepreneurial" efforts, one might even expect them to be better at it inasmuch as they would have had to run for office and persuade possibly resistant voters of the merits of their positions. If, as almost every American lawyer believes, the "life of the law" has at least as much to do with experience as with logic, then one would expect these differential experiences to be relevant. Whatever one thinks of present members of the United States Supreme Court, there is no reason to believe that any of them possesses a demonstrated capacity to speak to mass audiences or even practicing politicians and to persuade them to give the judges' own nostrums a try.

This being said, it is noteworthy that at least two of the current justices, Antonin Scalia and Stephen Breyer, seem increasingly to be engaged in self-conscious public campaigns to generate general support for their views of the Constitution. The path was certainly forged by Scalia, who often seems to be less interested in civil dialogue with his colleagues than in speaking "out of doors" to what political scientists call "attentive publics" who can mobilize social and political movements supporting his particular constitutional agenda. ${ }^{73}$ Breyer has apparently realized that one must, in effect, fight fire with fire, as evidenced not only by the publication of a recent book defending his own distinct

71. Id. at 1419 (quoting Nelson W. Polsby, Political InNOvation in America: The Politics of Policy INITIATION 171 (1984)); see also WAyne V. MCINTOSH \& CyNTHIA L. CATES, Judicial ENTREPRENEURSHIP: THE ROLE OF THE JUDGE IN THE MARKETPLACE OF IDEAS 1-22 (1997) (discussing the concept of judicial entrepreneurship).

72. Cross \& Lindquist, supra note 70 , at 1420.

73. See, e.g., Robert Post \& Reva Siegel, Originalism as a Political Practice: The Right's Living Constitution, 75 ForDHAM L. REV. 545, 565-68 (2006). 
perspective on constitutional matters - very much in opposition to Scalia's ${ }^{74}$ _but also his equally distinctive willingness to go on such programs as Larry King's CNN show to discuss the book. ${ }^{75}$ It is noteworthy as well that both Scalia and Breyer engaged in a joint "conversation" before a 4500-person audience at the Texas Tech School of Law, where they each, in effect, made their campaign pitches even though, obviously, they have lifetime tenure and, unlike the Iowa and other state judges, need not fear retribution from the electorate. ${ }^{76}$ It may be the case that judges who insist that their opinions speak for themselves and that it is undignified - or even a breach of judicial ethics - to defend one's views before the local Rotary Club and the like will be increasingly viewed as relics of a dying political culture, similar to presidential candidates who remained on their front porches and counted on surrogates to engage in the grubby task of persuading the voters to support them. If we can see this happening with justices of the United States Supreme Court, this would presumably be far likelier with regard to state court judges who must worry about remaining in the good graces of a potentially mercurial electorate.

There are, of course, also important substantive differences between - and among - most state constitutions and the United States Constitution. Consider, for example, the fact that only two of the fifty states have a so-called "unitary executive" in which the governor appoints the state's attorney general and may remove him at will. ${ }^{77}$ Even if one stipulates, for sake of argument, the dubious proposition that the correct interpretation of the United States Constitution is the requirement of a "unitary executive,"78 it is simply demonstrably false to say that conception of the executive branch is embedded in American political thought, given its overwhelming rejection by over ninety-five percent of the American states. Far more relevant to this essay, however, is another important substantive difference, which involves the character of the rights that are protected by the respective constitutions.

74. See generally Stephen Breyer, MaKing Our Democracy Work: A Judge's VieW (2010) (describing Breyer's perspective).

75. See ICYMI: Supreme Court Justice Stephen Breyer, LARRY KING LIVE (Sept. 16, 2010), http://larrykinglive.blogs.cnn.com/2010/09/16/icymi-supreme-court-justice-stephen-breyer/.

76. See Brooke Bellomy, Justices Scalia, Breyer Speak at Lecture Series, DaILY TOREADOR (Lubbock, TX), Nov. 14, 2010, available at http://www.dailytoreador.com/news/article_7bf7c942f04a-11df-b524-0017a4a78c22.html.

77. See, e.g., William P. Marshall, Break Up the Presidency? Governors, State Attorneys General, and Lessons from the Divided Executive, 115 YALE L.J. 2446, 2448 n.3 (2006) (noting that "[o]nly in Alaska and Wyoming does the Attorney General serve entirely at the Governor's behest").

78. See SteVen G. CAlabresi \& Christopher S. Yoo, The UnitARy EXeCUtive 3-9 (2008). 
It is a notorious truth about the United States Constitution that it is distinctly a "first-stage" exemplar of constitutionalism, written in the late Eighteenth century, when such constitutional rights as were deemed worthy of protection against state invasion were "negative rights" dealing with personal liberties. ${ }^{79}$ If "second-stage" constitutionalism focused as well on what might be termed "participatory rights," such as the right to vote or serve as a governmental official, then the modern age of constitutionalism, for better or-some would undoubtedly say-for worse has taken us to a "third stage" involving so-called "social" or "positive rights." Cass Sunstein recently wrote of the desirability of complementing the 1791 Bill of Rights by adopting Franklin D. Roosevelt's vision, articulated over sixty years ago, of a "second [social] bill of rights." ${ }^{\circ 0}$ No longer does the citizen want only, or even necessarily most of all, "the right to be let alone," described by Justice Brandeis as "the most comprehensive of rights and the right most valued by civilized men," 81 or even the fundamental right to participate in choosing and serving in one's government. Instead, the citizen, under this model, wants certain kinds of affirmative protections by the state against the vicissitudes of fate-what has come to be called the "welfare state." 82

It is difficult to find constitutions drafted after World War II, "liberal" or "illiberal," that do not include some of these welfarist provisions. Ironically or not, even constitutions drafted under the influence of the United States, such as the present Iraqi constitution, include constitutional guarantees going far beyond anything that can be found in the United States Constitution itself. Consider only Article 34, which first proclaims education to be "a fundamental factor in the progress of society" and then declares that "[f]ree education is a right for all Iraqis in all its stages." ${ }^{\text {"83 }}$ As every American law student knows, any such interpretation of the United States Constitution was rejected by a majority of the Supreme Court in a well-known 1973 case; whatever else

79. See, e.g., T. H. MARShall, Citizenship AND Social Class AND Other Essays 10-18 (1950).

80. CAss R. Sunstein, THE SECOND BILl OF Rights 1 (2005).

81. Olmstead v. United States, 277 U.S. 438, 478 (1928).

82. Given the recent prominence of libertarian politicians, such as newly elected Senator Rand Paul of Kentucky, it is altogether possible that at least some citizens are perfectly satisfied with the Brandeisian right of being left alone and have no wish whatsoever for a "safety-net" state responsive to welfare needs.

83. Article 34, Doustour Joumhouriat al-Iraq [The Constitution of the Republic of Iraq] of 2005, available at http://www.washingtonpost.com/wp-dyn/content/article/2005/10/12/AR2005101 201450.html. 
might be said about education, it was not a "fundamental right" or "interest" meriting judicial oversight—and intervention—regarding the adequacy or equality of state educational systems. ${ }^{84}$ At the very least, "the majority in Rodriguez tolerated the continuation of a funding system that allowed serious disparities in the quality of the education a child received based solely on the wealth of the community in which his parents happened to live or could afford to live." ${ }^{85}$ But it is unclear, as a constitutional matter, that the national Constitution, as interpreted by the Supreme Court, requires the state to operate a public school system at all, any more, say, than the state is required to operate a zoo or swimming pools. It would certainly not be shocking, in a descriptive legal sense, if the current majority of the Supreme Court believes that the provision of such goods might well, as a constitutional matter, be left entirely to the market, should that be the legislators' decision, with attendant consequences for those without sufficient resources to purchase the goods in question. If one takes the language of the Iraqi constitution seriously, that option is unavailable there.

\section{SCHOOL FinANCE LitigATION AS EXEMPLIFYING “DiALOGUE”}

As I've already suggested, one makes a profound error in confining one's understanding of American constitutionalism to the national Constitution and its interpretation by the Supreme Court. As Professor Hershkoff writes, "every state constitution in the United States addresses social and economic concerns, and provides the basis for a variety of positive claims against the government.... [M]ore than a dozen state constitutions provide explicit protections for the poor."86 Almost certainly the most important such right is education. According to Professor Dinan, "[e]ducation has long been considered the responsibility of state and local governments, ${ }^{, 87}$ and state constitutions

84. San Antonio Indep. Sch. Dist. v. Rodriguez, 411 U.S. 1, 37 (1973).

85. Jeffrey S. Sutton, Essay, San Antonio Independent School District v. Rodriguez and Its Aftermath, 94 VA. L. REV. 1963, 1971 (2008); see also Richard Schragger, San Antonio v. Rodriguez and the Legal Geography of School Finance Reform, in CIVIL RIGHTS STORIES 85 (Myriam E. Gilles \& Risa L. Goluboff eds., 2008).

86. Hershkoff, supra note 64, at 1135; see also Helen Hershkoff, “Just Words”: Common Law and the Enforcement of State Constitutional Social and Economic Rights, 62 STAN. L. REV. 1521, 1523-24 (2010) (listing specific positive rights guaranteed by various state constitutions); Emily Zackin, Positive Constitutional Rights in the United States (Nov. 2010) (unpublished Ph.D. dissertation, Princeton University) (on file with author) (an invaluable review of the positive rights tradition in American state constitutions).

87. DINAN, supra note 45, at 237. 
place upon states at least some affirmative duties to provide education to the young. As Dinan notes, the debates at various state constitutional conventions concerned not only the desirability of ensuring sufficient intellectual or vocational training, but also the role that education played in creating a sufficiently virtuous citizen, what Dinan calls the "moral development" of unformed youngsters. ${ }^{88}$ This surely helps to explain why "[a]bout one-fourth of state spending on average, or about \$275 billion, goes toward public education." ${ }^{89}$ And, incidentally, the undoubted relationship between education and moral development-or, at least, political socialization-helps further to explain why public dialogue about education might be especially intense and often acrimonious.

It should, then, occasion no surprise at all that Rodriguez in 1973 was scarcely the last word regarding litigation concerning the adequacy of America's public school systems. Although one might read Rodriguez as having given all of the American states "the green light" ${ }^{\text {"90 }}$ to continue the status quo in (inegalitarian) funding of public education, most states did not in fact continue in their usual practices. Instead, what Rodriguez did was to displace such litigation from the federal courts to state courts, where lawyers relied on state constitutional law instead of federal lawsave, of course, when litigation involved alleged racial discrimination, which certainly was a subject for analysis under the national Constitution, but for reasons having little or nothing to do with the specifics of education. ${ }^{91}$ Indeed, Justice Thurgood Marshall, in his anguished dissent in Rodriguez, explicitly noted that "nothing in the Court's decision today should inhibit further review of state educational funding schemes under state constitutional provisions."92 Few, if any, lawyers felt inhibited. As Douglas Reed notes, the constitutions of "[f]orty-nine of fifty states have an education clause that specifies some required level of public education; many, in fact, declare public

88. Id. at 238 .

89. Policy Basics: Where Do Our State Tax Dollars Go?, CTR. ON BudGet AND POLICY PRIORITIES, http://www.cbpp.org/cms/index.cfm?fa=view\&id=2783 (last updated Mar. 19, 2010).

90. Sutton, supra note 85, at 1971.

91. Original readers of Brown v. Board of Education would easily be forgiven for believing that the case-and therefore the Equal Protection Clause it interpreted-was significantly about education. Brown v. Bd. of Educ. of Topeka, 347 U.S. 483 (1954). After all, Brown referred to "education [as] perhaps the most important function of state and local governments," with compulsory education laws, common in many state constitutions and statutes, plus the sheer dollar amounts of state budgets devoted to education "demonstrat[ing] our recognition of the importance of education to our democratic society." Id. at 493.

92. San Antonio Indep. Sch. Dist. v. Rodriguez, 411 U.S. 1, 133 n.100 (Marshall, J., dissenting). 
education to be a fundamental state right."93 To be sure, the specific language of the various constitutions may differ quite a bit, but these differences are less important than the reality of the language being found in the state constitution in the first place. ${ }^{94}$ This may suggest that another difference between state and federal courts is that state judges, for a variety of reasons that might be worth exploring, may be in general far less concerned with academic "theories of constitutional interpretation" than with pragmatically effective ways of confronting what are deemed to be important state problems such as those raised by public education.

Thus the New Jersey Supreme Court, only twelve days after the decision of the United States Supreme Court in Rodriguez, issued a decision holding that the clause of the New Jersey Constitution requiring that the state operate a "thorough and efficient" system of public education was sufficient to warrant invalidation of the existing system of educational finance in the state. ${ }^{95}$ Equally relevant is that Robinson was the first of at least twenty-six decisions issued by the New Jersey state supreme court between 1973 and 2010 involving the financing of New Jersey schools. ${ }^{96}$ Similarly, as Richard Schragger has noted with regard to the extended aftermath of Rodriguez in its state of origin-Texasthere have been a plethora of state supreme court cases, beginning in 1989, that have confronted not only the abstract meaning of Texas's commitment to "an efficient system of public schools," as set out in its constitution, but also the actual response of the Texas legislature to one or another of the judicial decisions. ${ }^{97}$ Schragger describes a "patternthe state legislature adopting legislation and the courts striking down" that "would be repeated over the next twenty years" following the initial 1989 decision. ${ }^{98}$ These facts should be of great interest to anyone interested in the actuality of dialogue-or bargaining — between courts

93. Douglas S. Reed, On Equal Terms: The Constitutional Politics of Educational OPPORTUNITY 55 (2001).

94. See Karen Swenson, School Finance Reform Litigation: Why Are Some State Supreme Courts Activist and Others Restrained?, 63 ALB. L. REV. 1147, 1174-75 (2000). Swenson, after examination of an extensive data set, finds that "the strength of a state's constitutional education clause is not related to the likelihood that a court will find a school finance scheme constitutional." Id. at 1175 .

95. Robinson v. Cahill, 303 A.2d 273, 295 (N.J. 1973); see also MiCHAEL PARIS, FRAMING EqUAL OpPoRTUNitY: LAW AND THE POLITICS OF SCHOOL FinANCE REFORM 67-73 (2010) (extensively parsing Robinson).

96. A full listing of the cases can be found in PARIS, supra note 95, at 310-12.

97. Schragger, supra note 85 , at 104-07.

98. Id. at 104 . 
and either the public in general or other state institutions more particularly.

In some ways, it is almost bizarre to look at the United States Supreme Court as a partner in serious dialogue; even on those relatively rare occasions when it treats an issue of genuine interest to the public at large, ${ }^{99}$ it rarely returns repeatedly to such issues. Consider only that a full quarter-century elapsed before the Supreme Court took a successor case to the 1978 Bakke case involving "affirmative action" and higher education. ${ }^{100}$ And when, in 2003, the Court examined the undergraduate admissions system of the University of Michigan and a different admissions process used by the University of Michigan Law School, it split the baby in half by striking down the former and upholding the latter. ${ }^{101}$ It is clear that seven of the Justices believed this made no sense, but it didn't matter, since they split four to three on what would make collective sense and the two remaining judges, Justices O'Connor and Breyer, managed to discern a distinction in the two programs that did not impress their colleagues. ${ }^{102}$ Indeed, to try to have even a classroom dialogue about these two cases guarantees only collective frustration, since the seven other justices are almost certainly correct, and one is forced to teach students the equivalent of how to conjugate a decidedly irregular English verb.

If one is looking for dialogue from federal courts, the far better option, I suspect, is to look at circuit courts of appeal or, even more so, district courts. After all, as I learned while clerking for a district judge, the most important thing a judge does is to implement constitutional norms by constructing remedies-what my colleague Mitchell Berman calls "decision rules" in contrast to "interpretations" of the

99. See, e.g., Frederick Schauer, Foreword: The Court's Agenda-And the Nation's, 120 HARV. L. REV. 4, 32 (2006) (demonstrating the disconnect between what most interests the public and the topics addressed by the Supreme Court).

100. Regents of the Univ. of Cal. v. Bakke, 438 U.S. 265 (1978). And, of course, there was no "Opinion for the Court" in Bakke. Almost bizarrely, Justice Powell's opinion, which was in fact rejected by all of his colleagues, became treated as the de facto opinion of the Court, at least until the opinion of the Fifth Circuit Court of Appeals in Hopwood v. Texas, where Judge Smith, for the majority, emphasized that "Justice Powell's view in Bakke is not binding precedent on this issue. While he announced the judgment, no other Justice joined in that part of the opinion discussing the diversity rationale.” 78 F.3d 932, 944 (5th Cir. 1996), abrogated by Grutter v. Bollinger, 539 U.S. 306 (2003).

101. Gratz v. Bollinger, 539 U.S. 244, 275 (2003) (holding that the undergraduate admissions process violated the Equal Protection Clause); Grutter, 539 U.S. at 343 (holding the Michigan Law School process did not violate the Equal Protection Clause).

102. See Robert P. George, Gratz and Grutter: Some Hard Questions, 103 Colum. L. REV. 1634, 1634-35 (2003). 
Constitution. ${ }^{103}$ The United States Supreme Court is often content to write cryptic opinions enunciating some version of a right, ${ }^{104}$ while leaving it up to what the Constitution calls "inferior courts" actually to figure out how to instantiate the right, ${ }^{105}$ with minimal actual guidance from the Court and only sporadic intervention thereafter with regard to anything these "inferior" judges might do. ${ }^{106}$ One might, of course, speak of a dialogue between the Supreme Court and courts lower in the judicial bureaucracy, though, as a practical matter, one might wonder exactly how seriously many of the ostensibly subordinate judges take Delphic utterances ${ }^{107}$ from Washington, given their knowledge that the Supreme Court now takes extremely few cases to review. Over ninetynine percent of all cases come to an end well short of the Supreme Court. ${ }^{108}$ And, as suggested earlier, any such dialogue is distinctly

103. Mitchell N. Berman, Constitutional Decision Rules, 90 VA. L. Rev. 1, 9 (2004).

104. See, e.g., Brown v. Bd. of Educ. of Topeka (Brown I), 347 U.S. 483, 493 (1954) (stating a right to public education must be given to all on equal terms).

105. See, e.g., Brown v. Bd. of Educ. of Topeka (Brown II), 349 U.S. 294, 301 (1955).

106. See, e.g., Adam Liptak, The Roberts Court; Justices Long on Words but Short on Guidance, N.Y. TIMES, Nov. 18, 2010, at A1, available at http://www.nytimes.com/2010/11/ 18/us/18rulings.html?_r=1\&scp=AdamLiptakonjudicialopinions\&st=cse.

107. I cannot forbear quoting Anthony G. Amsterdam's own discussion of the Delphic Oracle, based on Par Lagerkvist's The Sibyl:

[T] he role of the Pythia, or priestess of the Oracle at Delphi, was of incomparable grandeur and futility. This young maiden was periodically lashed to a tripod above a noisome abyss, wherein her God dwelt and from which nauseating odors rose and assaulted her. There the God entered her body and soul, so that she thrashed madly and uttered inspired, incomprehensible cries. The cries were interpreted by the corps of professional priests of the Oracle, and their interpretations were, of course, for mere mortals the word of the God.

The Pythia ... was viewed with utmost reverence and abhorrence; enormous importance attached to her every utterance; but from the practical point of view, what she said didn't matter much....

To some extent, this Pythian metaphor describes the Supreme Court's functioning in all the fields of law with which it deals.

Anthony G. Amsterdam, The Rights of Suspects, in THE Rights of AMERICANS: What THEY ARE-WhAt THEy SHOUld BE 401, 401-02 (Norman Dorsen ed., 1971).

108. Professors Songer, Sheehan, and Haire report that, of the nearly 4000 decisions rendered by three circuits studied over the course of 1986, only nineteen, or less than half of one percent, were reviewed by the Supreme Court, and of these, only two-thirds were reversed, for a net non-reversal rate of 99.7\%. DONALD R. SONGER ET AL., CONTINUITY AND CHANGE IN THE UNITED STATES COURTS OF APPEALS 17 (2000). One might well believe that the likelihood of review has in fact gone down since 1986, inasmuch as the United States Supreme Court is in fact taking significantly fewer cases - in part because it has almost complete control over its own docket. Thus, for the 2008 term of the Court, the justices granted review in a total of eighty-seven of the 7868 appeals filed (1.1\%). The Supreme Court, 2008 Term-The Statistics, 123 HARV. L. ReV. 382, 389 (2009). Overall, the Supreme Court in that term issued the fewest number of written opinions since 1953. Linda Greenhouse, On the Court That Defied Labeling, Kennedy Made the Boldest Mark, N.Y. TIMES, June 29, 2008, at A1. See also generally Symposium, Important Questions of Federal Law: 
constrained by the fact that the Supreme Court can quash any suggestion, however reasonable, by one of its "inferiors" should there be five votes, for whatever reason, to reject it. In any event, if one is looking at the federal level for truly inter-institutional dialogue between the judiciary and other political institutions, my money would be on the usually unheralded, and minimally studied, district courts, ${ }^{109}$ or, with regard to administrative law, the Court of Appeals for the District of Columbia. That being said, I suspect that one will find many more examples of such dialogues - or whatever one might wish to call them-when scrutinizing the work of state courts.

But the sheer number of New Jersey or Texas decisions concerning the financing of their public school systems is not the only important thing worth noting. Also significant with regard to New Jersey, I think, is the fact that the state's Democratic Governor nominated as Chief Justice of the New Jersey Supreme Court in December 1973 his predecessor, two-term Democratic Governor Richard Hughes, a dedicated liberal who had suffered a stinging political defeat-by one vote in the New Jersey Senate-in his efforts to bring an income tax to New Jersey. ${ }^{110}$ He was confirmed by the New Jersey Senate and took office in $1974,{ }^{111}$ just after the initial decision in Cahill, but not too late to become a shaping force in the extended dialogue that took place between the Court and the New Jersey legislature and governor. As the New York Times stated in Hughes's obituary, "he was to play a key role in the enactment of the income tax" that he had unsuccessfully fought for as Governor, because of Cahill:

After Mr. Hughes was named Chief Justice by Gov. William T. Cahill in 1974, the court began prodding the Legislature to find a way to eliminate the inequities.

After Gov. Brendan T. Byrne and the Legislature battled for months over Mr. Byrne's proposal to enact an income tax, the Hughes-led court stepped into the controversy. In June 1976, the court ordered the

Assessing the Supreme Court's Case Selection Process, 119 YALE L.J. ONLINE 67 (2010), http://yalelawjournal.org/the-yale-law-journal-pocket-part/26/.

109. See generally, e.g., Joshua M. Dunn, Complex Justice: The CASE OF Missouri V. JENKINS (2008) (detailing the complex litigation history of a case involving Kansas City, Missouri, ultimately resolved in a five to four decision by the United States Supreme Court, 515 U.S. 70 (1995)).

110. See Joseph F. Sullivan, Richard J. Hughes, Governor and Judge, Dies at 83, N.Y. TimES, Dec. 8, 1992, at D1, available at http://www.nytimes.com/1992/12/08/us/richard-j-hughes-governorand-judge-dies-at-83.html?pagewanted=2 .

111. Id. 
closing of New Jersey's public schools until a new financing plan was approved. The decision broke the back of the opposition to the income tax. It was enacted and the schools were reopened. ${ }^{112}$

To put it mildly, it is difficult, if not impossible, to imagine the United States Supreme Court engaging in this kind of "constitutional showdown" ${ }^{\text {"113 }}$ with the New Jersey legislature.

I have already adverted to the extended dialogue that occurred between the state court and legislature in New Jersey, which is certainly not unique, as Michael Paris demonstrates in his book-length study of New Jersey and Kentucky, both of which saw dramatic constitutionally based decisions by their respective state supreme courts. ${ }^{114}$ And, if one adds Texas to this mix, we discover that the ensuing dialogue following judicial decisions included, at least some of the time, on both sides, politically sophisticated individuals. Chief Justice Hughes may well have been exceptional. He was, apparently, widely respected by politicians of both parties and by the public in general. His successor, Robert Wilentz, was a member of a politically active family-his father, according to the New York Times, "was a legendary Democratic Party power in New Jersey"-who had served two terms in the New Jersey legislature during the 1960s. ${ }^{115}$ Appointed Chief Justice to succeed Richard Hughes in 1979, he was the subject of an intense confirmation struggle because of alleged judicial activism in 1986 when he was reappointed by Republican Governor Thomas Kean, but he was approved for reappointment by a twenty-one to nineteen vote. ${ }^{116}$ "What made Justice Wilentz an effective chief justice, in the opinion of those who followed his career, was his ability to see political realities and his willingness to push for regulatory and administrative machinery to enforce the court's decrees. 'He didn't just make decisions and leave others to see to them,'” said one experienced New Jerseyite, who went

112. Id.

113. See generally Eric A. Posner \& Adrian Vermeule, Constitutional Showdowns, 156 U. PA. L. REV. 991 (2008) (discussing the concept of "constitutional showdowns").

114. See generally PARIS, supra note 95 (comparing the leading school finance reform cases in New Jersey and Kentucky).

115. David Stout, Robert Wilentz, 69, New Jersey Chief Justice, Dies; Court Aided Women and the Poor, N.Y. TIMES, July 24, 1996, at D1, available at http://www.nytimes.com/1996/07/ 24/nyregion/robert-wilentz-69-new-jersey-chief-justice-dies-court-aided-women-and-the-poor.html? pagewanted $=2$.

116. Id. 
on to describe him as " "a realistic politician who was willing to do the right thing.","117

It is worth noting similarities with Texas and Kentucky. Oscar Mauzy, a prominent liberal Democratic member of the Texas Senate, was elected to the Texas Supreme Court in 1987, and there can be little doubt that Mauzy viewed his membership on the court as an opportunity to achieve at least some of the goals that he had unsuccessfully advocated in the Texas legislature. ${ }^{118}$ He would be joined in 1989 by Lloyd Doggett, a similarly liberal state senator who had been defeated in an effort to become Texas's senator in Washington. ${ }^{119}$ Doggett would leave the court in 1994, when he was elected to the national House of Representatives. ${ }^{120}$ A Republican justice, John Cornyn, who served one term between 1991 and 1997, left to run, successfully, to become Attorney General of Texas, and he was subsequently elected to the United States Senate. ${ }^{121}$ Indeed, Professor Paris has commented that when "[l]ooking at [Texas] school finance, I often had the sense that I was looking at an additional legislative branch-politicians passing through." 122

Similarly, Kentucky Chief Justice Robert Stephens had, prior to his joining that state's highest court in 1979-by appointment of the Governor-been elected Attorney General of Kentucky in $1975 .{ }^{123}$ Interestingly enough, and illustrating yet another difference from the United States Supreme Court, Stephens was elected chief justice in 1982 by his fellow justices. ${ }^{124}$ One of the very few defects of the two leading books on the school finance litigation by political scientists is insufficient attention to such biographical facts about the judges presiding over their respective courts. One should not reduce these-or other-judges simply to their biographies, but it is a mistake to ignore their political careers, especially if, as part of a comparative project, one is interested in

117. Id.

118. See Oscar Mauzy, TEXAS STATE CEMETERY, http://www.cemetery.state.tx.us/pub/ user_form.asp?pers_id=5978 (last visited Apr. 1, 2011).

119. Lloyd Doggett (D), WASH. POST: POSTPOLITICS, http://projects.washingtonpost.com/ congress/members/D000399 (last visited Apr. 1, 2011).

120. Id.

121. Biography: Senator John Cornyn, SENATOR JOHN CORNYN, http://www.johncornyn. com/bio (last visited Apr. 1, 2011).

122. E-mail from Michael Paris to Sanford Levinson (May 17, 2010, 5:59 PM) (on file with author).

123. Former Chief Justice Robert Stephens Dies, DaILY News (Bowling Green, KY), Apr. 14, 2002, at 7A, available at http://news.google.com/newspapers?nid=1696\&dat=20020414\&id =EP4aAAAAIBAJ\&sjid=IEgEAAAAIBAJ\&pg=5709,1299362.

124. Id. 
distinguishing those states whose courts proved receptive to "reformist" law suits and those that did not.

After all, Professor Paris notes that since the 1973 defeat in the United States Supreme Court by those seeking reform in the funding of public education, "school finance litigation has been sustained, widespread, and ongoing." 125 By 2007, "lawsuits challenging state school finance systems had reached the high courts" of forty-three of the fifty American states. ${ }^{126}$ Plaintiffs_-self-styled "reformers"-_"prevailed in court in twenty-six states, and they have failed in seventeen." "27 As one might imagine, there might well be different notions of what it means to have "prevailed," especially if one is interested in translating judicial paragraphs into changes on the ground that truly affect the lives of one's clients. Hovering over this essay is the argument made most notably-or notoriously_in Gerald Rosenberg's The Hollow Hope: Can Courts Bring About Social Change?, which answered its subtitled interrogatory in the negative. ${ }^{128}$ Rosenberg appears to reject the plausibility of any strongly dialogical model of the judiciary, at least if we imagine a genuinely two-way dialogue in which courts might truly change the opinions and then the actions of the broad public to whom, by stipulation, they are speaking. If the audience for judicial opinions is confined to the specific litigants, then it is difficult to know exactly what "dialogue" might mean or, more to the point, why anyone would believe it is particularly important.

In any event, the educational finance cases offer a wonderful basis for examining a variety of questions that should be of interest to constitutional scholars, regardless of their particular methodologies. Is the primary explanation of the differences among the various states the political identity of state justices, whether "Democrat or Republican," "liberal or conservative?" Should we address the presence of "innovative" or "entrepreneurial" judges in one set of states as against the others?

More traditional lawyers might wish to focus on the internal language of the respective state constitutions and the opinions construing them. The various state constitutions offer a wide variety of examples. I

\footnotetext{
125. PARIS, supra note 95, at 46 .

126. Id.

127. Id. Judge Sutton, in his 2008 article, indicates that "as of June 2008, forty-five States have faced state-constitutional challenges to their systems of funding public schools," of which twentyeight were successful. Sutton, supra note 85, at 1974.

128. See generally Gerald N. Rosenberg, The Hollow Hope: CAn COURTS Bring About SOCIAL CHANGE? (1991).
} 
have already adverted to the New Jersey Constitution, with its injunction that the state provide a "thorough and efficient" program of public education, ${ }^{129}$ while Texans are informed by their constitution that "[a] general diffusion of knowledge being essential to the preservation of the liberties and rights of the people, it shall be the duty of the Legislature of the State to establish and make suitable provision for the support and maintenance of an efficient system of public free schools."130 Kentucky is quite laconic: "The General Assembly shall, by appropriate legislation, provide for an efficient system of common schools throughout the State."131

America's oldest operating constitution, older even than the national Constitution, is the Massachusetts Constitution, drafted in 1780 by John Adams. It expansively_and charmingly—notes that:

Wisdom, and knowledge, as well as virtue, diffused generally among the body of the people, being necessary for the preservation of their rights and liberties; and as these depend on spreading the opportunities and advantages of education in the various parts of the country, and among the different orders of the people, it shall be the duty of legislatures and magistrates, in all future periods of this commonwealth, to cherish the interests of literature and the sciences, and all seminaries of them; especially the university at Cambridge, public schools and grammar schools in the towns; to encourage private societies and public institutions, rewards and immunities, for the promotion of agriculture, arts, sciences, commerce, trades, manufactures, and a natural history of the country; to countenance and inculcate the principles of humanity and general benevolence, public and private charity, industry and frugality, honesty and punctuality in their dealings; sincerity, good humor, and all social affections, and generous sentiments among the people. ${ }^{132}$

As a justice of the Massachusetts Supreme Court put it, "The McDuffy case $^{133}$ was essentially an interpretation of a single word in the Massachusetts constitution,... 'cherish.' Was it mandatory or

129. See supra note 95 and accompanying text.

130. TEX. CONST. art. VII, § 1.

131. KY. CONST. § 183.

132. MASS. CONST. ch. V, § II.

133. See McDuffy v. Sec'y of Educ., 615 N.E.2d 516, 555-56 (Mass. 1993) (holding that the Massachusetts educational system was indeed subject to judicial scrutiny). The court later withdrew from the area in Hancock v. Comm'r of Educ., 822 N.E.2d 1134, 1139 (Mass. 2005) (holding that Massachusetts was meeting its constitutional charge to cherish the interests of public schools). 
aspirational? If it was aspirational, ... it doesn't mean much.”134 On the other hand, "[i]f the word was mandatory, courts can get involved, issue judgments, enforce them, and consider broad relief."135

Another difference between the United States Constitution and a number of state constitutions is that the latter are often considerably younger, not because new states have been recently admitted, but, rather, because states are quite willing to subject their constitutions to scrutiny and, on occasion, to replace an existing constitution with what is considered to be a document more suitable to the time. ${ }^{136}$ One of the newest state constitutions is that of Montana, adopted in 1972. The education section, entitled "Educational Goals and Duties," reads as follows:

(1) It is the goal of the people to establish a system of education which will develop the full educational potential of each person. Equality of educational opportunity is guaranteed to each person of the state.

(3) The legislature shall provide a basic system of free quality public elementary and secondary schools. The legislature may provide such other educational institutions, public libraries, and educational programs as it deems desirable. It shall fund and distribute in an equitable manner to the school districts the state's share of the cost of the basic elementary and secondary school system. ${ }^{137}$

State courts might therefore feel some special legitimacy in enforcing positive rights clauses given that they might be said to express the will of the contemporary people. It may not be surprising, then, that plaintiffs in Montana were able to prevail in suits testing the adequacy of the educational system. ${ }^{138}$

134. Michael A. Rebell, Courts \& Kids: Pursuing Educational Equity through the STATE COURTS 108 (2009).

135. Id.

136. A model, I fervently believe, that we should adopt at the national level.

137. MonT. COnST. art. X, § 1.

138. Columbia Falls Elementary Sch. Dist. No. 6 v. State, 109 P.3d 257, 263 (Mont. 2005) (holding that the educational product of the state public school system did not satisfy the state constitutional requirement that the state provide quality public education); Helena Elementary Sch. Dist. No. 1 v. State, 769 P.2d 684, 690 (Mont. 1989) (holding that the state failed to provide a system of quality public education because the state failed to adequately fund the foundation program). 
But, of course, one wonders how important these actual texts are as plausible explanations of wins and losses in given courts. Even more can one wonder - and doubt — whether any of the respective courts exhibited any interest in the "original understanding," however defined, of the drafters of the various constitutions. One is entitled to be skeptical on both counts, at least as an initial hypothesis. ${ }^{139}$ Consider only Professor Paris's description of Justice Stephens's seminal opinion in Kentucky, which declared unconstitutional every aspect of the existing Kentucky system of public education: ${ }^{140}$ "In interpreting the meaning of the education clause of the Commonwealth's constitution, the Court would elaborate and constitutionalize a set of fundamental principles only loosely tethered to the constitutional past. It would speak the language of constitutional aspiration." "141 Very important is Professor Paris's immediately following comment that this left "it to others to work out particular meanings in the days, years, and decades ahead." ${ }^{\text {"142 }}$ One might well describe such an opinion, whatever its conformity to one's favorite model of judicial opinion writing, as just the sort to encourage a freeform dialogue.

I will confess that the immediate free-association upon reading Professor Paris's comment was to opinions of the South African Constitutional Court interpreting their own positive-rights provisions in the remarkable constitution drafted in 1994 to signify the new constitutional order that was to succeed the oppressive apartheid state. That constitution is impressive for its declaration of positive rights, but it is also obvious that the present Republic of South Africa can only "aspire" to fulfill any such promises. Cass Sunstein has described that constitution as "the most admirable constitution in the history of the world," 143 not least because of its declaration of positive rights. Yet Sunstein has also praised the South African Constitutional Court for its "minimalist" efforts to enforce such rights inasmuch as their opinionswhile acknowledging the existence and importance of the provisionsseem only to require that the South African parliament make good-faith efforts over the years to adopt policies that might instantiate the

139. See Swenson, supra note 94 , at $1174-75$.

140. See Rose v. Council for Better Educ., 790 S.W.2d 186, 215 (Ky. 1989).

141. See PARIS, supra note 95, at 196 (emphasis added).

142. Id.

143. Mark S. Kende, The South African Constitutional Court's Embrace of Socio-Economic Rights: A Comparative Perspective, 6 CHAP. L. REV. 137, 138 (2003) (quoting CASS R. SUNSTEIN, DESIGNING DEMOCRACY 261 (2001)). 
aspirations underlying the provisions. ${ }^{144}$ This is, it should be noted, different from those completely "aspirational" constitutions such as Ireland's or India's, which explicitly forbid courts from adjudicating the meaning and impact of the positive-rights provisions in those constitutions. Any dialogue that will occur will be confined, presumably, to Irish and Indian legislators, unlike the case in South Africa (or Kentucky?).

It should be clear that any full treatment of the questions raised above-and the answers provided by what is now four decades of litigation in forty-five states-would require a far longer book than those written by Professors Reed and Paris, on which I am heavily drawing. Rather, I want to conclude by offering some of my own reflections about dialogue that have been provoked by my reading of these two excellent books and, perhaps, the experience of living in Texas throughout the “Edgewood era” following Justice Mauzy's 1989 decision.

One conclusion upon reading this literature is that, to some degree at least, Gerald Rosenberg is simply wrong. The public education systems of a number of states were significantly affected by litigation attacking especially the existing systems of school finance. In at least one state, New Jersey, this led ultimately to the adoption of a state income tax, one of the most contentious subjects on the state's political agenda. ${ }^{145}$ The Texas legislature, for example, has proved absolutely unwilling to consider any such radical legislation, which means that schools in Texas continue to be funded substantially by property taxes, with important political ramifications. ${ }^{146}$ That being said, and even though Texas has become quite decisively Republican since the days of Edgewood I in 1989-indeed, Justice Mauzy was defeated in his 1992 bid for reelection to the court and, subsequently, the court became entirely Republican, with various consequences for the theories adopted with regard to the continuing school finance cases-school funding has changed substantially, at least if measured by both absolute and relative dollar amounts. Thus, in 1989, Texas's wealthiest districts spent \$19,333 per student, whereas only $\$ 2112$ per student were available to the poorest districts. ${ }^{147}$ By 1995, when Mauzy was off the Court and Edgewood IV came down, "the state equalized the funding for eighty-five percent of

\footnotetext{
144. See Cass R. Sunstein, Social and Economic Rights? Lessons from South Africa (Univ. of Chicago, Pub. L. Working Paper No. 12, 2001), available at http://papers.ssrn.com/ sol3/papers.cfm?abstract_id=269657.

145. See PARIS, supra note 95, at 138-39.

146. See Schragger, supra note 85, at 104-05.

147. Id. at 105.
} 
the students at any given tax rate, with the richest schools outpacing the poorest by only $\$ 600 . "{ }^{\prime 48}$ And the shift to greater state responsibility for school funding has survived the Republican takeover of statewide politics. $^{149}$

San Antonio's specific story in this regard is especially interesting, though one has to be attentive to the fact that major political changes were also taking place that, for example, produced San Antonio's first Hispanic mayor and majority city council. ${ }^{150}$ In any event, "[i]n 20032004, state aid helped Edgewood outspend Alamo Heights [the richest school district in the San Antonio area] $\$ 8,670$ to $\$ 8,201$, and both exceeded the statewide average of $\$ 7,784$ per student." Schragger notes the limits of such moves toward equality: "Edgewood [which continues to be ninety-two percent Hispanic, with twenty-five percent of its students below the poverty line] test scores are still far below those in Alamo Heights [which is seventy-five percent Anglo and only four percent poor]."152 Alas, this conforms with the general pattern that "[a]cross metropolitan areas, schools are highly segregated, and performance differences between inner-city schools and suburban schools are striking." 153 Perhaps one would be resistant to seeing this new glass as even half-full, but it appears difficult to deny that some significant changes have taken place and that various state courts are at least part of the explanation.

Almost no one today would accept a model of judicial supremacy, especially at the state level, in which courts speak and the rest of the political system listens attentively and changes relevant behaviors to satisfy the judges. So what does explain some of these changes beyond the sheer power of the court? Michael Paris's fascinating book Framing Equal Opportunity: Law and the Politics of School Finance Reform, makes the very important point that litigation strategies in New Jersey and Kentucky, in particular, were significantly different. ${ }^{154}$ From a lawyer's perspective, the most important of the differences involved the nature of the legal arguments per se: New Jersey lawyers, for example, focused much more on the equitable issues involved in school finance and the patent inequalities of funds received by students depending on

\footnotetext{
148. Id.

149. Id. at 106-07.

150. See id. at 106.

151. Id. at 107.

152. Id.

153. Id.

154. See PARIS, supra note 95.
} 
whether they lived in rich or poor-which in New Jersey often correlated very heavily with white or African-American-cities, ${ }^{155}$ whereas Kentucky's reforms emphasized almost exclusively whether all of Kentucky's children were being given at least a minimally "adequate" education and satisfied the Kentucky Supreme Court that the answer was no. ${ }^{156}$ The Texas litigation, especially at its initial stages, was far more like New Jersey's. But Paris makes another extremely important argument, which may be of far more interest to political scientists and anyone interested in the nature of inter-institutional dialogue.

Paris describes the New Jersey reformists, at least initially, as "legalists," who did indeed fit Rosenberg's model of placing extremely high hopes in the consequences of being able to prevail in court. ${ }^{157}$ "Armed with nothing but the tools of their trade, a few lone-ranger attorneys would seek to produce social change by judicial decree."158 To an astonishing degree, they were successful in prevailing before the New Jersey Supreme Court. ${ }^{159}$ But, as Paris notes, "the immediate results would be disappointing." 160 But, recall, there were twenty-six subsequent opinions written by the court by 2009, and by the end of the process, even if the results continued to be disappointing from what might be termed, non-pejoratively, a "maximalist" perspective-as with Texas, no one argues that the contemporary New Jersey public school system is a model of social justice or necessarily "effective" education for all of its students-at least some poor (and African-American) students have presumably benefitted, and the reason for this is the ability of the initially "lone-ranger attorneys" to begin operating effectively with a variety of education-related interest groups and publics in order to confront the strong opposition to any significant reform at all. But it did take a remarkably long time, one might believe, for the lawyers to recognize the importance of politics more generally. Thus "until the early 1990s [twenty years after the initial litigation], the [Education Law Centerdirecting the litigation] never sought to use its litigation to organize new groups or to otherwise mobilize potential constituents in politics.”161 Particularly telling — and, from one perspective, appalling-

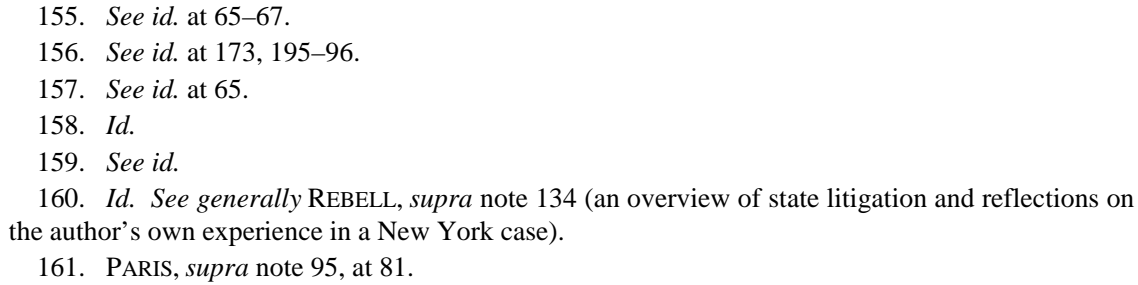


as an illustration of "the ELC's legalism" was its desire for what Paris terms "nominal, or phantom, clients," that is, poor students who could be evoked but whose parents need not actually be consulted or, more to the point, organized as a genuine political force. ${ }^{162}$ "The ELC thereby enjoyed the moral authority of speaking for poor victimized children without having to answer to any live political organizations or formations about its litigation strategy and that strategy's relationship to politics.”163 Indeed, a recurring question in the literature involving "public-interest lawyering" is the degree to which the lawyers in fact pay very much attention to the expressed desires of their putative clients. ${ }^{164}$ Most would-be leaders_or "authorities" - in fact prefer "monologues," at least if they are the speakers-and actors-over necessarily more messy “dialogues” that may threaten one’s own prerogatives.

Even in New Jersey, though, the reformers could genuinely feel they had won substantial victories, described as "compelling" and even "stunning" by Paris. ${ }^{165}$ What we cannot know, of course, is whether this actually vindicates their strategy or whether a more overtly political strategy, designed to generate the kind of public dialogue that comes through strong participation of interest groups and potential voters, might have had even better results. In any event, Paris describes a significantly different litigation strategy in Kentucky, where reformers developed not only a quite different image of what was at stake—saving the "common school" project rather than achieving abstract norms of distributive justice-but also, and crucially, a different conception of how to integrate litigation in a wider political movement. ${ }^{166}$ This becomes crucial in explaining the fact that within a year of the Kentucky Court's momentous decision in 1989 declaring, in its own words, that “'Kentucky's entire system of common schools is unconstitutional,,"167 the Kentucky legislature "passed an ambitious omnibus measure called the Kentucky Education Reform Act... [that] sought to change the whole education system, all at once."168 Indeed, by 2005, "the school finance changes produced substantially higher education spending in

\footnotetext{
162. Id.

163. Id. at 81-82 (emphasis added).

164. See generally Derrick A. Bell, Jr., Serving Two Masters: Integration Ideals and Client Interests in School Desegregation Litigation, 85 YALE L.J. 470 (1976) (the classic article addressing such issues).

165. PARIS, supra note 95, at 91.

166. See id. at 159-64.

167. Id. at 159 (quoting Rose v. Council for Better Educ., 790 S.W.2d 186, 215 (Ky. 1989)).

168. Id. at 160 .
} 
each school district and substantially more spending equally across all districts." 169 There was, as Paris notes, "very little resistance” to Rose ; $^{170}$ there were no cries of judicial usurpation or invocations of the "countermajoritarian difficulty.,"171

Unlike his chapters on New Jersey, which often feature detailed examinations of judicial opinions, most of Paris's chapters on Kentucky emphasize the overall political milieu. By 1989, educational reformers had created a broad coalition, cutting across predictable lines, in favor of attacking-and changing-the existing public school system. ${ }^{172}$ "Various educational interest groups had mobilized in support of the Council's lawsuit." 173 So why was a lawsuit necessary at all? The answer is that "an antitax governor and leading legislators had come to a stalemate over competing education reform programs and taxes." ${ }^{174}$ The function of the Kentucky Supreme Court was in effect to "br[eak] this institutional logjam," which, among other things, "provided the elected officials with cover on the tax question. The court's decision, then, did not create conditions conducive to reform but rather merely threw a much-needed spark into an already combustible mix of heightened agitation and conflict." ${ }^{175}$ One cannot help but think once more of Mark Graber's seminal work emphasizing the way that courts with some frequency take on certain political hot potatoes with the approval, if not the outright delight, of those in political power who cannot, for whatever reason, surmount a veto point generated by the complexities of American political institutions. ${ }^{176}$

Paris notes, incidentally, that by staying away from issues of distributive justice in its opinion-and focusing instead only on the "quality" of Kentucky education-the Kentucky Court avoided the epithet that was quickly placed on the programs generated by having to respond to the explicitly equity-oriented decision of the Texas Supreme Court written by the strongly liberal Justice Oscar Mauzy. ${ }^{177}$ Legislative attempts to respond to the court were quickly termed "Robin Hood" bills,

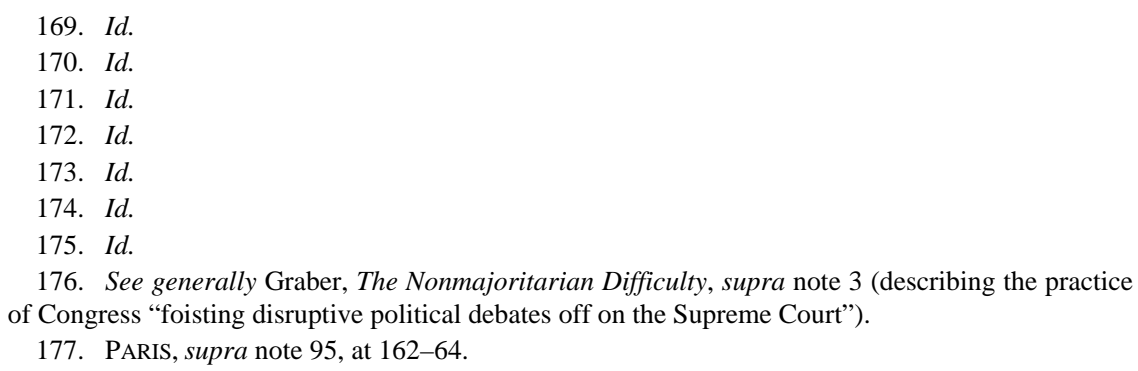


since, as is true of all seriously redistributive legislation, it indeed took tax funds, generated through property taxes, from the rich, and gave them to far poorer students. ${ }^{178}$ Not surprisingly, there were recurrent showdowns between - and among - the Texas state legislature, Texas courts, including the Texas Supreme Court, and the public of Texas, given that constitutional amendments in Texas require ratification by the general public. Thus, a proposition placed on the ballot by the Texas legislature that would have allowed consolidation-and thus pooling of property tax revenues - of independent school districts went down to stinging defeat in 1993, not least, one suspects, because "the major opposition group” named itself “Texans Against Robin Hood Taxes." "179

In 1991, it is probably worth noting, the popular and widely respected Lieutenant Governor of Texas, William P. Hobby, had called for the electoral defeat of all nine Texas Supreme Court justices following the issuance of so-called Edgewood II, which appeared to call for Robin Hood policies as the means of enforcing the norms set out in the initial Edgewood decision in 1989. ${ }^{180}$ Furthermore, Professor Reed notes, the court responded to the controversy following Edgewood II by issuing, only four weeks later, yet another opinion "most likely in response to negative press and legislative reaction," in which the court "changed its mind about a key element of the 'Robin Hood' proposal."181 Thus, Reed argues, the Texas Supreme Court, by failing "to provide policy leadership" or any "analytical clarity" that would "enunciate clear constitutional policy options for the state legislature, produced a protracted and bitter struggle that compounded an already difficult political situation."182 Whatever one's theory of "dialogue," the Texas Supreme Court appears to be close to an "anti-model" of how any such dialogue should be conducted, though it should be recognized, as noted earlier, that even under these circumstances Texas did significantly change its process of school financing. ${ }^{183}$

Kentucky is a dramatic contrast. "[W]hat is noteworthy about the Kentucky case is that reformers' broader democratic efforts meant that [the] Kentucky Supreme Court never had to take any remedial plunge at

178. See REED, supra note 93, at 116-17 (discussing attempts by the Texas legislature to redistribute property tax revenue and opposition to these efforts by Texans Against Robin Hood Taxes).

179. Id. at 117.

180. Id. at 72 .

181. Id. at 73 .

182. Id.

183. See supra notes $146-48$ and accompanying text. 
all. Indeed, it would actually reject all hints that there might be judicial management of the legislative process or education policy ....”" ${ }^{\text {,84 }}$ By resolutely offering a "non-remedy," the court in effect allowed elected officials to take "the lead in constituting a comprehensive reform law that soon became a model for the rest of the country." "185 One might, I suppose, wonder if this serves as a model of "dialogue," if the ending is far happier, in many ways, than in Texas, precisely because the major role of the Kentucky court was to engage in a "bold stroke" that "propped up the legislature in its fight with the governor" and, in addition, "offered up a broad and inspiring rhetorical argument that called on others," who the court knew were waiting for just such an invitation, "to seize the moment—-to make history."

\section{CONCLUSION}

It is obvious that much more could be said. What I hope I have done is the following:

(1) To demonstrate that any analysis of "American constitutionalism" must include due attention to the constitutions of the fifty states and not, as is usual, be limited to the United States Constitution, which differs in significant ways from many of the state constitutions. Not only will one find a number of interesting things to reflect on, one might also appreciate the force of Donald Lutz's reference to the national Constitution as an "incomplete text" that presumed the existence of states and their own constitutional commitments. ${ }^{187}$ Recall that the 1780 Massachusetts Constitution adverted to the importance of education as a state responsibility.

(2) To suggest- “demonstrate” is probably too strong a term, until further research is done- that for a variety of reasons, dialogue may be far more likely with regard to state constitutions and the meanings assigned to these constitutions by state judiciaries than is the case if we focus only on federal courts, particularly the United States Supreme Court. I am not arguing that dialogue with that institution is impossible or that it has never occurred, especially with regard to statutory

\footnotetext{
184. PARIS, supra note 95, at 192.

185. Id. at 193 .

186. Id. at 192.

187. See generally Donald S. Lutz, The United States Constitution as an Incomplete Text, 496 ANNALS AM. ACAD. POL. \& Soc. SCI. 23 (1988). I owe this reference to an interesting paper by then-Princeton Ph.D. candidate Emily Zackin, "Are State Constitutions Really Worse Than the Federal One?”, which I am grateful to Ms. Zackin for sending me.
} 
interpretation, where Congress obviously can have the last word. Instead, the occasions for any such dialogue, I suggest, are few and far between. There are many potential explanations for this, ranging from the limited formal accountability, particularly of members of the Supreme Court, to other institutions or, even more certainly, to the electorate, to the sheer fact that the modern Court takes very few cases that genuinely concern most members of the public, and it is extremely easy, much of the time, to confine any rulings that might be issued-in what are often bitterly contentious five to four opinions - to very particular facts or contexts that might well be distinguished from ostensibly similar cases in other states. All parents quickly learn that dialogues with their children may require that the parents present a "united front," given a child's remarkable skill in picking up signals of divisions between the parents, and even a united parental unit must expect—and respond to-repeated challenges. Similarly, one wonders if a court that models discord and, not infrequently, acrimonious exchanges among the conflicting judges, can generate effective dialogues with others except insofar as a five-justice majority remains stalwart in its views and basically heedless of those who disagree, whether other justices, political institutions, or the public at large.

Moreover, any significant dialogue about the United States Constitution, including Supreme Court decisions interpreting the document, that raises the possibility of constitutional amendment immediately runs into the brick wall of functional impossibility, given the stringency of Article V. This makes those who propose such dialogues_-as I can testify to personally - appear to be at best utopian, at worst simply Quixotic in a decidedly unflattering sense. For whatever reason, more consequential dialogues may be possible in at least some of the American states than within the wider United States.

(3) At some point, one has to address the eighteenth century debate about the size limits on something that might be called a "Republican Form of Government," which, for most analysts, includes overtones of dialogues among the citizenry in general and between ordinary citizens and those who govern them in particular. When Madison defended the possibility of the "extended republic," he was writing of a country of almost four million people, of whom most were excluded from political life because of gender or status as slaves-not to mention property requirements in some colonies and states. Today the state of California, which contains roughly one-eighth of the total population of the United States today, is itself is almost ten times as large in population as the original United States. And, of course, the percentage of this vast total that has the right to participate in political decision-making is also far 
greater than could have been imagined in 1787. Perhaps dialogue is perfectly sensible to contemplate in Canada, which is smaller in population than California; Australia, slightly larger than Texas; and New Zealand, which is roughly the same size as Minnesota. Whether it makes much sense in the United States can be questioned, at least if the dialogue is imagined to include literally millions of Americans rather than, say, a representative sample. ${ }^{188}$

(4) In all cases, it is almost certainly a mistake to use judicial supremacy or dialogue as dichotomous variables. Courts are, I suspect, relatively unable, especially with regard to the kinds of positive rights that concern this paper, to foist truly major change on a political system that is truly resistant. But it is clear that one must distinguish the different kinds of dialogical models that are presented in New Jersey, Kentucky, and Texas, which, obviously, are only three of the plethora of states whose courts have involved themselves, in one way or another, in what most people might describe as "educational reform." As always in comparative work, it is unclear exactly what can be learned from close attention to some of these differences. Even if it is true, for example, that dialogue with the public is promoted by the popular election of judges, is that a good reason to support such elections? If a key variable is the desirability of having judges with practical political experience and an ability to generate compromises among otherwise conflicting groups, then that presumably could become more of a criterion for appointing at least some judges, even if one might also appreciate the presence of some judges who have led more cloistered lives-and who, perhaps, take "constitutional theory" more seriously than do most ordinary political activists.

This supports the view that one must view courts more as a "team"or perhaps an "orchestra" - than a collection of discrete individuals, so that one has to have a conception of the various players or instruments that are necessary when making selections. Just as no rational football coach or orchestra conductor would continue drafting or selecting wide receivers or violinists indefinitely and would instead try to fill the need for interior linemen or oboists, so should anyone thinking of a multimember court think of the range of talents that one wants represented and try to make sure that as many of them as possible are in fact found in

\footnotetext{
188. See James S. Fishkin, When the People Speak 96-105 (2009); Sanford Levinson, Democracy and the Extended Republic: Reflections on the Fiskinian Project, 19 GOOD SOC'Y 63, 63-67 (2010).
} 
a given court, even if it is obviously unlikely that any given judge would instantiate all of them. 